\title{
KONFLIK PEMILIHAN KEPALA DUSUN DEPOK AMBARKETAWANG GAMPING SLEMAN YOGYAKARTA
}

\author{
Denanda Putri Adhilani dan Farida Hanum \\ Jurusan Pendidikan Sosiologi, FIS, UNY \\ e-mail: denandaadhilani97@gmail.com
}

\begin{abstract}
Abstrak
Penelitian ini mendeskripsikan latar belakang, faktor penyebab, dan upaya yang sudah dilakukan untuk menyelesaikan konflik pemilihan kepala dusun Depok Ambarketawang. Penelitian ini menggunakan metode kualitatif deskriptif. Pengambilan sampel menggunakan teknik purposive sampling dengan jumlah informan 8 orang. Teknik pengumpulan data dilakukan dengan wawancara, observasi, dan dokumentasi. Validitas data yang digunakan adalah triangulasi sumber. Teknik analisis data menggunakan teknik analisis data milik Miles dan Huberman meliputi pengumpulan data, reduksi data, penyajian data, dan penarikan kesimpulan. Hasil dari penelitian ini menunjukkan bahwa konflik tersebut dilatar belakangi oleh pemilihan kepala dusun melalui musyawarah dusun dan tes. Faktor penyebab konflik tersebut adalah kurangnya pemahaman masyarakat tentang peraturan daerah yang baru, dukuh terpilih tidak sesuai dengan keinginan masyarakat, kurangnya sosialisasi pada masyarakat tentang calon dukuh, dan adanya pengaruh dari kelompok tertentu. Adapun upaya yang sudah dilakukan untuk mengatasi konflik pada pemilihan kepala dusun tersebut antara lain kepala desa berusaha menjelaskan peraturan daerah yang baru pada masyarakat, negosiasi yang dilakukan oleh kepala desa, mediasi mempertemukan dukuh terpilih dengan masyarakat, dan dukuh terpilih mengundurkan diri.

Kata Kunci: Konflik, Pemilihan, Kepala Dusun
\end{abstract}

\section{Abstract}

This research describes the background, causes, and attempts done in resolving the conflict occurred in the election of the village chief in Depok, Ambarketawang. The method used in this study was descriptive qualitative means. The sample was obtained from 8 informants through the purposive sampling method. The data was collected through interviews, observation, and documentation. The data validity used in this study was the methodological triangulation. This research used Miles and Huberman's model in order to analyse the data; the method consists of data collection, data reduction, data presentation, dan drawing conclusion. The result of this research shows that the conflict was caused by the means of the election, i.e. a discussion and test. The conflict occurred due to the local people's inadequate knowledge of the latest local regulation, undesired chief candidate by the local people, inadequate information shared regarding the candidate, and influences brought by some group. There were some attempts done in order to resolve this issue such as the urban village head's attempt in explaining the new local regulation to the local people, negosiation, mediation done to help the winning candidate reconcile with the local people, and the winning candidate's resignation.

Keywords: Conflict, election, village chief

\section{Pendahuluan}

Berdasarkan hasil data Potensi Desa (Podes) tahun 2018, Badan Pusat Statistik (BPS) mengungkapkan bahwa di Indonesia terdapat 75.436 desa yang terdiri dari tiga kategori yaitu desa mandiri sebanyak 5.606 desa (7,43\%), desa berkembang sebanyak 
55.369 desa $(73,4 \%)$, dan desa tertinggal sebanyak 14.461 desa $(19,17 \%)$ (www.kompas.com). Menururt data tersebut desa yang tergolong mandiri hanya $7,43 \%$ dan desa yang masih tertinggal sebesar $19,1 \%$. Sehingga di Indonesia membutuhkan upaya pembangunan dan pengembangan desa menuju kemandirian. Salah satunya melalui pemberlakuan Undang- Undang Desa Nomor 6 Tahun 2014 tentang Desa. Berdasarkan undang- undang tersebut desa diberi kewenangan untuk mengatur dirinya sendiri atau yang disebut otonomi desa. Kewenangan dan kebutuhan masyarakat dapat terpenuhi apabila didukung oleh pengembangan dan pembangunan desa yang optimal.

Desa dalam melakukan pengembangan dan pembangunan membutuhkan sumber daya manusia yang berkualitas dengan didukung oleh sarana prasarana memadai. Oleh karena itu, setiap pemerintah desa diharapkan memiliki aparatur dan perangkat desa yang berkualitas dalam hal intelektual, kinerja, maupun kepribadiannya. Sehingga aparatur dan perangkat desa mampu menjalankan tugas dan wewenangnya secara optimal untuk meningkatkan kemajuan desa. Untuk mewujudkan aparatur pemerintah yang sesuai dengan tujuan undang- undang tersebut, maka diperlukan mekanisme seleksi pemilihan perangkat desa yang bisa dipertanggungjawabkan dan sesuai dengan peraturan perundangundangan. Oleh karena itu, memunculkan peraturan daerah tentang tata cara pengangkatan dan pemberhentian perangkat desa yang berisi pemilihan perangkat desa melalui seleksi tes. Salah satunya Peraturan Daerah (Perda) Sleman Nomor 16 Tahun 2016 tentang Tata Cara Pengangkatan dan Pemberhentian Perangkat Desa.

Berlakunya Peraturan daerah (Perda) Sleman Nomor 16 tahun 2016 tentang tata cara pengangkatan dan pemberhentian perangkat desa, maka perangkat desa termasuk kepala dusun (Dukuh) dipilih tidak dengan pemilihan melainkan melalui jalur musyawarah dusun dan seleksi tes. Pemilihan perangkat desa yang dilakukan melalui seleksi tes, harapannya perangkat desa terpilih merupakan seseorang yang benar- benar berpotensi, bertanggungjawab, dan bukan terpilih berdasarkan keturunan atau pendukung. Perda ini mulai diterapkan di Desa Ambarketawang pada tahun 2017 dan dilaksanakan pertama kali pada pemilihan kepala dusun Depok di bulan Mei 2017.

Partisipasi masyarakat dalam seleksi pemilihan kepala dusun di Depok Ambarketawang Gamping ini berbentuk dukungan saat musyawarah dusun (musdus) dengan perwakilan warga 
memberikan voting kepada calon kepala dusun sesuai dengan pilihannya. Sedangkan panitia pemilihan beranggotakan perangkat desa yang ditunjuk oleh kepala desa. Tahap demi tahap seleksi pemilihan kepala dusun dilakukan oleh panitia hingga terpilihlah kepala dusun dan dilakukan pengangkatan oleh kepala desa. Namun, masyarakat menganggap bahwa dalam musyawarah dusun dan penentuan hasil seleksi pemilihan kepala dusun, masyarakat tidak dilibatkan secara penuh. Sehingga masyarakat kontra terhadap hasil seleksi pemilihan kepala dusun tersebut.

Pemberlakuan Perda tersebut justru mengakibatkan terjadinya konflik karena kepala dusun yang terpilih berdasarkan seleksi tes tersebut tidak sesuai dengan keinginan dan harapan masyarakat. Sehingga masyarakat melakukan berbagai aksi protes di kantor desa dan kecamatan. Tuntutan dan keinginan warga yang tidak dipenuhi tersebut mendorong konflik yang semakin memuncak terjadi hingga satu tahun mulai dari Mei 2017 hingga Mei 2018.

Konflik yang terjadi dalam masyarakat khususnya di daerah pedesaan dapat mengganggu hubungan sosial dan pelaksanaan kegiatankegiatan yang sifatnya membutuhkan partisipasi masyarakat. Dalam konflik yang terjadi di Dusun Depok ini, pihak kepala desa dan pemerintah desa sudah melakukan berbagai upaya untuk mengatasi konflik tersebut. Namun, pemerintah desa belum menemukan solusi netral yang tidak melanggar aturan dan juga tidak merugikan pihak- pihak tertentu hingga akhirnya kepala dusun mengundurkan diri dari jabatannya.

Berdasarkan realita yang ditemukan di lapangan dan kajian penelitian terdahulu, maka peneliti mengkaji terkait "Konflik Pemilihan Kepala Dusun Depok Ambarketawang Gamping Sleman Yogyakarta". Selain itu, konflik pemilihan kepala dusun akibat hasil seleksi tes ini belum banyak dikaji dalam penelitian- penelitian sebelumnya sehingga peneliti tertarik untuk mengkajinya lebih mendalam. Sehingga harapannya konflik yang sama tidak terjadi di daerah lain mengingat kebijakan pemilihan perangkat desa melalui seleksi tes ini merupakan kebijakan baru.

Populasi dalam penelitian ini adalah masyarakat Dusun Depok, Ambarketawang, Gamping. Sedangkan teknik pengambilan sampel dalam penelitian ini menggunakan purposive sampling Sumber Data Sekunder

Sumber data tertulis dalam penelitian ini adalah dokumen yang berupa arsip hasil seleksi pemilihan kepala dusun yang mendukung 
penelitian ini.

\section{Metode}

Penelitian ini mengambil lokasi di Dusun Depok, Ambarketawang, Gamping, Sleman, Yogyakarta. Menggunakan metode penelitian kualitatif dengan paparan deskriptif analisis. Sedangkan Teknik pengumpulan data menggunakan observasi, wawancara, dan dokumentasi. Pemilihan informan dalam penelitian ini menggunakan teknik purposive sampling. Sumber data primer dalam penelitian ini adalah 8 informan yang terdiri dari Kepala Desa Ambarketawang, ketua panitia seleksi pemilihan Kepala Dusun, Kepala Dusun Depok, tokoh masyarakat, dan masyarakat yang secara teknik purposive sampling dianggap memiliki informasi paling banyak tentang konflik pemilihan kepala dusun di Depok Ambarketawang tersebut.

\section{Hasil dan Pembahasan}

1. Latar Belakang Konflik Pemilihan Kepala Dusun Depok Ambarketawang Gamping Sleman Yogyakarta

Konflik di Dusun Depok Ambarketawang, Gamping, Sleman, Yogyakarta ini diawali oleh pemilihan kepala dusun berdasarkan Peraturan Daerah (Perda) Sleman Nomor 16 Tahun
2016 tentang Tata Cara Pengangkatan dan Pemberhentian Perangkat Desa. Dalam peraturan daerah tersebut mekanisme pemilihan kepala dusun tidak lagi dilakukan melalui pemilihan langsung oleh masyarakat, tetapi berdasarkan musyawarah dusun dan tes tertulis. Langkah pertama yang dilakukan oleh Pemerintah Desa yaitu berdasarkan surat keputusan Kepala Desa membentuk panitia pemilihan kepala dusun yang mana anggotanya adalah perangkat desa.

Berdasarkan hasil wawancara dapat diketahui bahwa mekanisme seleksi pemilihan kepala dusun adalah pertama diadakannya sosialisasi dari Pemerintah Desa terkait pencalonan kepala dusun di Depok tersebut dan syarat- syaratnya. Kemudian masyarakat yang tertarik mendaftarkan diri ke panitia dengan mengumpulkan syarat- syarat yang sudah ditentukan. Setelah seleksi administrasi calon kepala dusun, maka dilakukan Musyawarah Dusun (Musdus) dengan mekanisme calon yang mendapatkan minimal 2 suara dapat mengikuti seleksi jenjang berikutnya. Awalnya calon berjumlah 5 orang, tetapi yang lolos mengikuti musdus hanya 4 orang. Musyawarah Dusun dilakukan melalui voting perwakilan masyarakat yang dilaksanakan di Kantor Pemerintah Desa Ambarketawang. Peserta musyawarah dusun tersebut adalah 
perwakilan dari tokoh masyarakat dan 23 warga dari setiap RT di Dusun Depok. Adapun tokoh masyarakat yang terlibat antara lain Ketua RT, Ketua RW, Ketua KKLPMD, PKK, Karang Taruna, dan tokoh agama. Sehingga tidak semua masyarakat ikut berpartisipasi dalam pemilihan kepala dusun ini.

Setelah 4 calon kepala dusun lolos tahap seleksi selanjutnya, kemudian ada 1 calon mengundurkan diri sehingga hanya 3 calon yang lolos tes tertulis. Namun, pada saat ujian salah satu calon sakit sehingga hanya 2 calon yang mengikuti tes tertulis. Dalam tes tertulis ini calon kepala dusun mengikuti tes soal umum yang dibuat oleh kabupaten kerjasama dengan UNY, kemudian tes muatan lokal yang dibuat oleh panitia sendiri, tes praktek komputer yang penilaiannya kerjasama dengan perguruan tinggi. Kepala Desa menekankan pada panitia untuk bersih dari kecurangan dalam seleksi pemilihan kepala dusun ini. Sehingga pelaksanaan seleksi pemilihan kepala dusun ini dijamin tidak ada kecurangan.

Perhitungan hasil seleksi pemilihan kepala dusun meliputi $70 \%$ hasil ujian dan $30 \%$ hasil musdus. Ketiga calon kepala dusun memperoleh nilai akhir sebagai berikut: Pertama, S memperoleh nilai ujian 0 dan hasil musdus 4 sehingga nilai akhir 5,00. Kedua, $P$ memperoleh nilai ujian 44,9 dan hasil musdus 10 sehingga nilai akhir 43,93. Ketiga, $\mathrm{MH}$ memperoleh nilai ujian 67,6 dan hasil musdus 6 sehingga nilai akhir 54,75. Berdasarkan hasil perhitungan tersebut $\mathrm{MH}$ mendapatkan nilai tertinggi. Hasil seleksi pemilihan kepala dusun diumumkan secara transparan oleh panitia dengan menayangkannya pada layar di kantor Desa Ambarketawang. Namun, setelah kepala dusun dilantik ada sebagian warga yang mengeluarkan keluh kesahnya pada tokoh masyarakat bahwa mereka tidak setuju jika dipimpin oleh dukuh terpilih. Untuk menindak lanjuti keluh kesah warga tersebut maka tokoh masyarakat menemui kepala desa.

Warga membentuk kelompok dengan nama Forum Peduli Depok. Kelompok tersebut beranggotakan warga yang kontra terhadap dukuh terpilih. Tujuan dibentuknya kelompok ini untuk memudahkan dalam megumpulkan aspirasi warga dan memperjuangkan kepentingan bersama yaitu warga Depok. Waktu itu warga Dusun Depok meminta kepala desa untuk memberhentikan kepala dusun terpilih, tetapi berdasarkan peraturan yang berlaku kepala desa tidak dapat memberhentikan dukuh terpilih karena tidak melakukan pelanggaran sesuai dengan peraturan daerah yang berlaku. Sehingga tokoh masyarakat baik RT, RW, Ketua KKLPMD, Karang Taruna, dan PKK mengundurkan diri dari 
tugasnya masing- masing. Segala bentuk kegiatan di Dusun Depok tersebut tidak berjalan, kegiatan yang berjalan hanya kegiatan yang melibatkan warga pro dukuh seperti kegiatan posyandu dan PKK.

Warga Dusun Depok melakukan demo sebanyak 7 kali, baik yang dilakukan di kantor Desa Ambarketawang, kantor Kecamatan Gamping, maupun di perempatan jalan masuk Dusun Depok. Konflik tersebut terjadi antara warga kontra Dusun Depok dengan kepala dusun terpilih dan warga yang pro. Dalam demo tersebut warga menuntut kepala dusun terpilih untuk mengundurkan diri dari jabatannya. Namun, kepala dusun terpilih tetap bersikukuh tidak ingin mengundurkan diri dari jabatannya karena beliau ingin mengabdi pada masyarakat sesuai dengan sumpah jabatan yang sudah dilakukannya. Hal tersebut mengakibatkan warga semakin panas bahkan mereka juga membuat tulisantulisan penolakan yang dipasang di sepanjang jalan Depok sekaligus membakar ban di perempatan jalan masuk Dusun Depok. Konflik tersebut terjadi selama 1 tahun sejak Mei 2017 hingga Mei 2018.

Dampak adanya konflik ini mengakibatkan kurang harmonisnya hubungan antarwarga di Dusun Depok ini. Hubungan yang kurang baik tersebut juga berdampak pada terhambatnya pelaksanaan program atau kegiatan di Dusun Depok tersebut. Selain itu, surat menyurat yang dibutuhkan warga juga menjadi terkendala karena warga tidak mau meminta tanda tangan kepada dukuh terpilih. Bahkan warga menolak didata oleh tim pemilu dan menyatakan golput dari pemilihan umum 2019 apabila kepala dusun tetap menjabat. Hal tersebut sesuai dengan yang dijelaskan oleh informan

Konflik pemilihan Kepala Dusun Depok Ambarketawang ini termasuk konflik vertikal. Konflik ini terjadi antara masyarakat dengan pemimpin yaitu kepala dusun terpilih. Kedua belah pihak memiliki kedudukan yang berbeda, kepala dusun sebagai penentu kebijakan, sedangkan masyarakat sebagai pihak yang dikuasai. Selain konflik vertikal, konflik pada pemilihan kepala dusun di Depok Ambarketawang ini juga terdapat konflik horizontal antara masyarakat kontra dengan masyarakat pro. Namun, konflik horizontal tersebut tidak begitu tampak karena masyarakat pro cenderung menarik diri dari konflik. Bentuk konflik tersebut hanya sebatas desas desus ataupun saling menjelekkan antar keduanya, tidak sampai tindakan pertikaian. Mengingat jumlah masyarakat kontra jauh lebih banyak dari masyarakat pro dalam konflik tersebut. 
2. Faktor Penyebab Konflik Pemilihan Kepala Dusun Depok Ambarketawang Gamping Sleman Yogyakarta

Faktor penyebab konflik pemilihan Kepala Dusun Depok Ambarketawang Gamping Sleman ini antara lain :

a. Kurangnya Pemahaman Masyarakat tentang Peraturan Daerah yang Baru

Berdasarkan Peraturan
Daerah Sleman Nomor 16 Tahun
2016 tentang Tata Cara
Pengangkatan dan Pemberhentian
Perangkat Desa, pemilihan
perangkat desa khususnya kepala
dusun yang awalnya dipilih melalui
pemilihan warga berubah menjadi
musyawarah dusun dan tes. Masyarakat khususnya di pedesaan sudah terbiasa dengan kultur pemilihan langsung saat memilih pemimpin sehingga saat menerapkan seleksi tes pada pemilihan kepala dusun justru memunculkan kontra masyarakat. Hal ini tidak lain akibat kurangnya pemahaman masyarakat tentang peraturan daerah yang baru tersebut. Dalam musyawarah dusun tidak semua masyarakat bisa ikut berpartisipasi, hanya tokoh masyarakat dan perwakilan setiap RT saja yang dapat ikut memberi suara calon kepala dusun dalam musyawarah. Sedangkan hasil akhir dari seleksi pemilihan tersebut bergantung pada tes. Dalam hal ini masyarakat merasa tidak dilibatkan secara penuh dan kepala dusun yang terpilih tidak sesuai dengan harapan mereka. Sehingga memunculkan kontra masyarakat yang berujung konflik hingga satu tahun di Depok Ambarketawang ini. Kurangnya pemahaman masyarakat terhadap peraturan daerah yang baru tersebut juga mendorong masyarakat beranggapan bahwa seleksi tes hanya reka- reka dari panitia di pemerintah desa.

b. Dukuh Terpilih tidak Sesuai dengan Keinginan Masyarakat

Masyarakat yang terdiri dari individu dengan berbagai karakter tentu memiliki kriteria berbeda- beda dalam memilih pemimpin. Khususnya masyarakat desa yang mendambakan pemimpin berjiwa sosial tinggi dan baik pula akhlak pribadinya. Terlebih pemimpin yang dekat dengan warga tentu lebih banyak mendapatkan dukungan. Sehingga seleksi pemilihan kepala dusun di Depok Ambarketawang ini berujung konflik karena kepala dusun terpilih tidak sesuai dengan harapan masyarakat. Walaupun secara kemampuan kepala dusun terpilih memiliki potensi intelektual 
yang baik terlihat dari hasil seleksi tes. Kemudian kepala dusun terpilih merupakan seorang mahasiswa sehingga memiliki nilai positif dalam hal kemampuan strategi kebijakan dalam pembangunan desa maupun masyarakat. Namun, berdasarkan penjelasan warga, kepala dusun terpilih sebelum mencalonkan diri jarang mengikuti organisasi kemasyarakatan dan kurang bergaul dengan warga sekitar khususnya Dusun Depok ini. Selain itu, sebagian masyarakat tidak simpati dengan keluarga kepala dusun terpilih karena dianggap tidak transparan dalam menjalankan tanggung jawabnya.

Hal tersebut sesuai dengan karakteristik dan tradisi masyarakat desa yang masih memiliki sifat- sifat paguyuban. Sehingga masyarakat kurang terbuka terhadap perubahan yang ada, pemilihan kepala dusun yang awalnya berdasarkan pilihan masyarakat kemudian berubah menjadi seleksi tes. Pemilihan masyarakat desa tersebut umumnya berdasarkan kharisma seseorang di lingkungan masyarakat dan latar belakang keluarganya. Oleh karena itu, kepala dusun terpilih yang tidak sesuai dengan harapan masyarakat tersebut memunculkan protes dan berujung konflik di Dusun Depok ini. c. Kurangnya Sosialisasi pada Masyarakat tentang Calon Dukuh

Berlakunya Peraturan Daerah Sleman Nomor 16 Tahun 2016 tentang Tata Cara Pengangkatan dan Pemberhentian Perangkat Desa khususnya kepala dusun ini merupakan yang pertama diterapkan di Dusun Depok. Masyarakat sebagai pihak yang dipimpin oleh kepala dusun terpilih tentunya ingin mengetahui calon kepala dusun beserta visi misinya. Namun, dalam mekanisme seleksi tersebut tidak diawali dengan sosialisasi pengenalan calon kepala dusun kepada masyarakat. Sehingga mekanisme langsung pada tahap musyawarah dusun dan masyarakat belum mengetahui kandidat calon kepala dusun beserta visi misinya. Dalam hal ini masyarakat menganggap bahwa mereka tidak dilibatkan dalam seleksi pemilihan kepala dusun karena masyarakat belum mengetahui bagaimana visi misi calon kepala dusun sebelum dipilih pada musyawarah dusun.

d. Adanya Pengaruh dari Kelompok Tertentu

Awal potensi konflik pada pemilihan kepala dusun di Depok ini sebenarnya tidak murni dari seluruh warga. Namun, kesamaan pola pikir 
dan tujuan mendorong warga lain untuk ikut terlibat dalam konflik ini hingga hampir $90 \%$ warga menolak kepala dusun terpilih tersebut. Kelompok tertentu tersebut berasal dari pendukung lawan calon maupun warga yang tidak menyukai kepala dusun terpilih. Masyarakat kontra awalnya tidak banyak yang muncul, tetapi berjalannya waktu karena berbagai pengaruh menyebabkan konflik berkepanjangan hingga satu tahun.

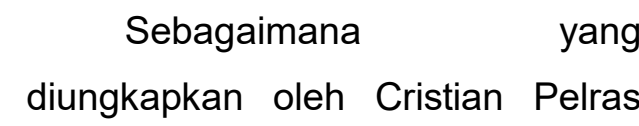
(dalam Ichsan, 2016:30) bahwa masyarakat memiliki sifat patron klien yaitu hubungan tidak setara yang terjalin secara perorangan antara seorang pemuka masyarakat (patron) dengan sejumlah pengikutnya (klien). Dalam konflik ini, ada pengaruh kelompok tertentu hingga akhirnya meluas menjadi sebagian besar masyarakat kontra terhadap dukuh terpilih. Hal tersebut tidak terlepas dari pengaruh patron klien, khususnya pada masyarakat desa yang masih sangat menghargai tokoh masyarakat yang menjadi panutan. Salah satu ciri- ciri patron klien sendiri adalah ketergantungan klien pada patron akibat jasa patron, dalam hal ini tokoh masyarakat sudah banyak berjasa untuk warga baik dalam hal hubungan sosial, politik, maupun ekonomi. Sehingga masyarakat secara otomatis dapat terpengaruh dengan hal tersebut, terlebih dalam hal ini memiliki kepentingan yang sama yaitu sama- sama tidak menyukai kepala dusun terpilih. Oleh karena itu, konflik yang berawal dari isu- isu kontra masyarakat tersebut berujung menjadi konflik yang berkepanjangan hingga satu tahun lamanya. Selain itu, berdasarkan analisis hasil wawancara hampir 90\% warga menolak kepala dusun terpilih dan menginginkan kepala dusun mengundurkan diri dari jabatannya.

$$
\text { Konflik pada masyarakat }
$$
khususnya dalam hal ini konflik pemilihan kepala dusun Depok Ambarketawang tidak terlepas dari adanya faktor penyebab yang memunculkan konflik berkepanjangan. Faktor penyebab konflik pada pemilihan kepala dusun di Depok Ambarketawang ini berkaitan dengan kajian Soerjono Soekanto tentang penyebab konflik yaitu adanya perbedaan kepentingan. Perbedaan kepentingan ini antara masyarakat kontra dengan kepala dusun maupun masyarakat pro. Masyarakat kontra menginginkan 
pemimpin yang sesuai dengan harapannya dan menuntut kepala dusun terpilih untuk mengundurkan diri dari jabatannya. Namun, disisi lain kepala dusun ingin tetap mengabdi kepada masyarakat sesuai dengan sumpah jabatannya sehingga tidak ingin mengundurkan diri. Selain itu, jabatan pemimpin yang dalam hal ini kepala dusun memiliki posisi kekuasaan yang tinggi di masyarakat. Oleh karena itu, tidak sedikit masyarakat yang ingin menempati posisi kekuasaan tersebut. Kemudian masyarakat pro memiliki kepentingan yang berlawanan dengan masyarakat kontra, pihak pro mendukung apabila kepala dusun terpilih menjadi pemimpin di dusun tersebut dan tidak setuju apabila masyarakat melakukan aksi demo menuntut kepala dusun terpilih untuk mengundurkan diri. Adanya perbedaan kepentingan dari beberapa pihak tersebut maka memunculkan konflik di Dusun Depok Ambarketawang tersebut.

3. Upaya yang Sudah Dilakukan untuk Menyelesaikan Konflik Pemilihan Kepala Dusun Depok Ambarketawang Gamping Sleman Yogyakarta

Adapun upaya yang sudah dilakukan untuk mengatasi konflik tersebut adalah sebagai berikut:

a. Kepala Desa Melakukan Sosialisasi Peraturan Daerah yang Baru pada Masyarakat

Kepala desa bersama perangkat desa mengadakan musyawarah bersama tokoh masyarakat dan masyarakat dengan tujuan sosialisasi terkait peraturan daerah yang baru yaitu Perda Sleman Nomor 16 Tahun 2016 tentang Tata Cara Pengangkatan dan Pemberhentian Perangkat Desa. Kepala desa berusaha menjelaskan kepada masyarakat bagaimana mekanisme pemilihan perangkat desa khususnya dalam hal ini kepala dusun menurut Perda baru tersebut. Seleksi melalui musyawarah dusun dan tes tersebut memang murni dari peraturan baru tanpa ada campur tangan dari pemerintah desa. Namun, masyarakat tetap tidak bisa menerima penjelasan tersebut dan tetap menuntut kepala desa untuk memberhentikan atau dukuh terpilih tersebut mengundurkan diri. Oleh karena itu, upaya penyelesaian konflik melalui musyawarah sosialisasi peraturan daerah yang baru tersebut tetap tidak memberi perubahan pada konflik di Dusun Depok ini. 
b. Negosiasi yang Dilakukan oleh penyelesaian konflik dengan Kepala Desa

Penyelesaian konflik kepala dusun dengan masyarakat ini, kepala desa melakukan negosiasi. Negosiasi ini dilakukan oleh kepala desa pada dukuh terpilih maupun tokoh masyarakat dan masyarakat Dusun Depok. Kepala desa meminta dukuh terpilih untuk mendekatkan diri pada warga, berusaha mendengarkan apa yang mereka harapkan. Kemudian kepala desa juga meminta masyarakat untuk memberi waktu pada dukuh terpilih agar dirinya bisa membuktikan kinerja jabatannya tersebut. Saat masyarakat demo di kantor Desa Ambarketawang, kepala desa juga melakukan negosiasi dengan meminta masyarakat untuk memberi waktu 6 bulan kepada dukuh terpilih. Upaya penyelesaian konflik melalui negosiasi oleh kepala desa tidak berhasil, konflik tersebut justru semakin meradang dan masyarakat tetap menuntut kepala dusun untuk mengundurkan diri dari jabatannya.

c. Mediasi Mempertemukan Dukuh Terpilih dengan Masyarakat

Penyelesaian konflik ini, Kepala Desa Ambarketawang memiliki peran sebagai mediasi. Menurut Soekanto \& Budi (2013:7071) mediasi merupakan suatu mendatangkan pihak ketiga yang bersifat netral dalam perselisihan yang ada. Pihak ketiga tersebut tugas utamanya adalah untuk mengusahakan suatu penyelesaian secara damai sehingga pihak ketiga hanya sebagai penasihat belaka dan tidak mempunyai wewenang untuk memberi keputusan- keputusan penyelesaian perselisihan tersebut. Untuk mediasi ini kepala desa mempertemukan kedua belah pihak yaitu dukuh terpilih dan masyarakat dengan tujuan agar keduanya bisa saling mengutarakan segala keluh kesahnya guna mendapatkan suatu kesepakatan bersama. Dalam hal ini kepala desa bersikap netral, berusaha mendengarkan penjelasan dukuh terpilih dan keluh kesah masyarakat. Namun, mediasi ini justru menyebabkan situasi semakin memanas, masyarakat menuntut kepala dusun terpilih untuk mengundurkan diri. Mediasi yang dilakukukan pada konflik pemilihan kepala dusun ini tidak berhasil karena kurang kuatnya keputusan antara kedua belah pihak.

d. Dukuh Terpilih Mengundurkan Diri Segala upaya sudah dilakukan, tetapi konflik tersebut tetap tidak ditemui jalan keluarnya. Satu tahun menjabat sebagai kepala 
dusun dengan berbagai aksi kontra masyarakat, akhirnya dukuh terpilih memilih untuk mengundurkan diri dari jabatannya. Sikap dukuh terpilih yang mengundurkan diri tersebut menjadikan konflik ini dinyatakan selesai. Setelah pengunduran diri, masyarakat mulai mengaktifkan kembali ketua RT, RW, KKLPMD, Karang Taruna, maupun PKK. Selain itu, masyarakat mulai berkenan untuk didata dalam pemilihan umum 2019 yang sempat terhambat karena mereka menolak mengikuti pemilu jika kepala dusun tidak mengundurkan diri.

Kepala dusun sebagai pihak yang lemah dalam konflik ini memilih untuk menyudahi konflik dengan mengundurkan diri dari jabatannya. Apabila dikaitkan dengan kajian upaya penyelesaian konflik termasuk dalam upaya coercion, dalam konflik ini terdapat paksaan dari masyarakat kontra sebagai posisi kuat dan kepala dusun terpilih sebagai posisi yang lemah. Masyarakat kontra terus melakukan protes bahkan berhenti dari kegiatan dusun yang secara tidak langsung melakukan paksaan psikologis pada kepala dusun terpilih dan masyarakat pro.

Berdasarkan analisis hasil wawancara, seleksi pemilihan kepala Dusun Depok ini berjalan dengan transparan dan tanpa ada kecurangan dari berbagai pihak karena seleksi dilaksanakan melalui jalur tes yang bekerjasama dengan universitas. Sehingga dalam pelaksanaan seleksi pemilihan kepala dusun tidak ada unsur atau perilaku konstelasi politik seperti politik uang. Seleksi pemilihan kepala dusun ini dilakukan dengan musyawarah dusun dan seleksi tes yang mendapatkan pengawasan dari berbagai pihak dengan langsung menayangkan hasil seleksi secara transparan. Dalam konflik pada pemilihan kepala dusun ini konstelasi politik justru muncul setelah hasil seleksi pemilihan kepala dusun resmi diumumkan dan dilantik. Hal tersebut terlihat dari sikap kontra masyarakat terhadap hasil seleksi. Masyarakat memperjuangkan kepentingannya tersebut dengan mengadakan demo dan tokoh masyarakat mengundurkan diri dari wewenangnya yang berujung konflik. Sikap kontra masyarakat ini termasuk bentuk strategi politik dalam memperjuangkan pemimpin yang sesuai dengan harapan mereka.

Konflik pemilihan Kepala Dusun Depok Ambarketawang ini 
apabila dianalisis menggunakan model analisis pemetaan konflik SIPABIO milik Amr Abdalla (dalam Susan, 2010:98-99) maka terdiri dari beberapa indikator. Pertama, sumber konflik dalam konflik ini adalah hasil seleksi pemilihan kepala dusun melalui jalur tes tidak sesuai dengan harapan masyarakat. Kedua, isu- isu dalam konflik ini adalah tidak sejalannya tujuan dari masyarakat kontra, kepala dusun, dan masyarakat pro. Masyarakat kontra memiliki tujuan posisi kepala dusun diduduki oleh seseorang yang menjadi harapannya dan menuntut kepala dusun terpilih untuk mengundurkan diri. Sedangkan kepala dusun terpilih yang didukung oleh masyarakat pro ingin tetap mengabdi menjadi pemimpin. Ketiga, pihak berkonflik dalam konflik ini adalah kepala dusun terpilih, masyarakat kontra, dan masyarakat pro. Keempat, sikap dalam konflik ini berupa persepsi masyarakat kontra yang menganggap bahwa kepala dusun terpilih tidak pantas menjadi pemimpin dan beranggapan seleksi ujian hanya reka- reka dari pemerintah desa. Sehingga hal tersebut memunculkan desas desus dalam masyarakat dan memunculkan aksi konflik. Kelima, perilaku konflik ini adalah aksi demo masyarakat di Kantor Desa Ambarketawang, aksi membakar ban bekas, maupun aksi menulis spanduk penolakan yang dipasang di pinggir jalan Dusun Depok. Keenam, campur tangan pihak lain dalam konflik ini adalah Kepala Desa Ambarketawang sebagai mediator dan Polres Gamping sebagai keamanan saat aksi demo berlangsung. Ketujuh, hasil akhir dari konflik ini berupa situasi dan hubungan yang kurang harmonis antara masyarakat kontra dengan masyarakat pro pasca konflik berlangsung.

Konflik pemilihan kepala dusun di Depok ini berkaitan pula dengan pemikiran Dahrendorf tentang tiga tipe kelompok dalam konflik yaitu kelompok semu, kelompok kepentingan, dan kelompok berkonflik. Sebagaimana dalam konflik pada pemilihan kepala dusun ini terdapat kelompok semu, kelompok kepentingan, dan kelompok berkonflik. Kelompok semu dalam konflik ini adalah masyarakat yang menyimpan rasa kontra dengan kepala dusun terpilih, tetapi mereka masih menyimpannya. Sedangkan kelompok kepentingan dalam konflik ini adalah masyarakat yang tidak 
menyukai kepala dusun terpilih maupun masyarakat pendukung lawan dalam pemilihan kepala dusun ini. Kelompok semu akibat pengaruh dari kelompok kepentingan dapat masuk menjadi kelompok kepentingan. Kemudian yang terakhir kelompok berkonflik adalah masyarakat kontra dan masyarakat pro yang terlibat dalam konflik tersebut.

Menurut Dahrendorf dalam teori konfliknya kedudukan dalam masyarakat diserahkan pada kekuasaan dan kewenangan. Sedangkan wewenang sendiri tidak terletak dalam individu, tetapi dalam kedudukan dan kewenangan. Dalam posisi wewenang dan orang yang berada diposisi bawahan memiliki kepentingan tertentu yang berlawanan. Hal ini sejalan dengan konflik pada pemilihan kepala dusun di Depok Ambarketawang, kedudukan kepala dusun memiliki wewenang dan kekuasaan di dusun tersebut. Wewenang dan kekuasaan tersebut berupa hak untuk mengatur dan memutuskan suatu kebijakan di suatu daerah yang dalam hal ini lingkup dusun. Kepala dusun sebagai individu yang memiliki kekuasaan dapat menentukan segala kebijakan yang ditaati dan dilaksanakan oleh masyarakat.
Selain itu, berdasarkan UndangUndang Desa Nomor 6 Tahun 2014 perangkat desa termasuk kepala dusun memperoleh penghasilan tetap setiap bulannya, jaminan kesehatan, dan dapat memperoleh penerimaan lainnya yang sah. Seperti di desa- desa kepala dusun mendapatkan tanah pelungguh berupa sawah. Oleh karena itu, tidak sedikit masyarakat yang ingin menduduki posisi kekuasaan tersebut.

Dahrendorf juga mengungkapkan bahwa kelompok kepentingan laten bisa menjadi kelompok kepentingan manifest apabila terdapat salah satu dari keempat indikator. Salah satunya yang sesuai dengan kajian konflik pemilihan kepala dusun ini yaitu memiliki anggota- anggota yang berkomitmen dan berkomunikasi diantara sesama. Berdasarkan hasil penelitian didapatkan bahwa pada awalnya masyarakat kontra hanya orang tertentu yang dalam hal ini termasuk kelompok kepentingan manifest, tetapi setelah dilakukannya musyawarah warga dan dibentuknya suatu kelompok Forum Peduli Depok maka berjalannya waktu jumlah masyarakat kontra semakin banyak. Kelompok kepentingan laten 
berubah menjadi kelompok kepentingan manifest akibat adanya komitmen yang kuat dari masyarakat dan komunikasi yang terjalin dalam kelompok tersebut.

Weber (2006:192) juga mengungkapkan bahwa dalam kekuasaan struktur politik memiliki suatu prestise khusus dalam masyarakat. Prestise yang dimaksud Weber adalah kekuasaan yang dalam praktiknya mencakup kekayaan maupun kekuasaan atas komunitas- komunitas lainnya. Berkaitan dengan konflik pada pemilihan kepala dusun di Depok Ambarketawang ini jabatan kepala dusun dalam suatu masyarakat memiliki prestise. Kepala dusun sebagai seorang pemimpin suatu dusun memiliki kekuasaan atas masyarakat di dusun tersebut. Sehingga tidak sedikit individu yang menginginkan menduduki posisi tersebut. Weber mengungkapkan bahwa ada tiga tipe kewenangan yaitu kewenangan tradisional, karismatik, dan legal rasional. Dalam konflik ini kekuasaan kepala dusun termasuk kewenangan legal rasional karena masa jabatan berdasarkan peraturan yang berlaku. Berdasarkan Peraturan Daerah Sleman Nomor 16 Tahun 2016 tentang Tata Cara Pengangkatan dan Pemberhentian Perangkat Desa, kepala dusun dipilih berdasarkan musyawarah dusun dan tes. Sehingga hasil seleksi tidak dapat diganggu gugat. Sebagaimana dalam konflik ini Kepala Desa Ambarketawang tidak dapat memberhentikan kepala dusun terpilih, meskipun masyarakat kontra dan terjadi demo yang berujung konflik karena kepala dusun tidak melanggar undangundang yang berlaku. Sehingga wewenang kepala dusun sepenuhnya berdasarkan peraturan yang berlaku.

\section{Simpulan}

Konflik di Dusun Depok Ambarketawang Gamping dilatar belakangi oleh berlakunya Peraturan Daerah Sleman Nomor 16 Tahun 2016 tentang Tata Cara Pengangkatan dan Pemberhentian Perangkat Desa. Dalam peraturan tersebut perangkat desa termasuk kepala dusun tidak lagi dipilih melalui pemilihan langsung, tetapi dengan musyawarah dusun dan tes tertulis maupun praktik. Pemberlakuan peraturan tersebut justru mengakibatkan masyarakat kontra dan berujung konflik di Depok Ambarketawang karena kepala dusun terpilih tidak sesuai dengan harapan masyarakat.

Konflik di Dusun Depok ini yang 
terjadi hingga satu tahun dari Mei 2017 hingga Mei 2018. Adapun faktor penyebab konflik politik pada pemilihan kepala dusun di Depok Ambarketawang ini antara lain kurangnya pemahaman masyarakat tentang peraturan daerah yang baru, dukuh terpilih tidak sesuai dengan keinginan masyarakat, kurangnya sosialisasi pada masyarakat tentang calon dukuh, adanya pengaruh dari kelompok tertentu.

Adapun upaya yang sudah dilakukan untuk mengatasi konflik pada pemilihan kepala dusun tersebut antara lain kepala desa melakukan sosialisasi peraturan daerah yang baru pada masyarakat, negosiasi yang dilakukan oleh kepala desa, dan mediasi mempertemukan dukuh terpilih dengan masyarakat. Berbagai upaya telah dilakukan, tetapi tetap tidak berhasil menyelesaikan konflik tersebut sehingga penyelesaian terakhir adalah kepala dusun mengundurkan diri dari jabatannya.

\section{Ucapan Terima Kasih}

Terimakasih disampaikan kepada semua pihak yang terlibat dalam penelitian ini sehingga terlaksana dengan baik dan tim redaksi Jurnal Pendidikan Sosiologi Fakultas IImu Sosial UNY yang telah mempublikasi penelitian ini

\section{Daftar Pustaka}

Halili,"Praktik Politik Uang dalam Pemilihan Kepala Desa (Studi di Desa Pekandangan Barat Bluto Sumenep Madura)", Jurnal Humaniora (Lemlit UNY), Volume 14., No 2, 2009, hal 99-112.

Muspawi, M, "Manajemen Konflik (Upaya Penyelesaian Konflik dalam Organisasi)", Jurnal Penelitian Universitas Jambi Seri Humaniora, 2014, hal 41-46.

Rachmawati, Nukita, \& Rusdian N D, "Konstelasi Politik dalam Novel Roro Jonggrang Karya Budi Sardjono Sebuah Pendekatan Sosiologi Sastra", Jurnal Caraka, Volume 2, No 2, 2017, hal 50-61.

Fantastic, Chevy. 2014. Konflik Politik dalam Proses Pemilihan Kepala Desa tahun 2007 di Desa Tarempa Barat Kecamatan Siantan Kabupaten Kepulauan Anambas. Naskah Skripsi Publikasi. IImu Pemerintahan Fakultas IImu Sosial dan Politik Universitas Maritim Raja Ali Haji Tanjung Pinang.

Ichsan, Fadli. 2016. Hubungan Patron Klien dalam Pemilihan Kepala Desa Tahun 2015 di Desa Kampala Kecamatan Arungkeke Kabupaten Jeneponto. Skripsi S1. Program Studi IImu Politik. Fakultas Ushuluddin, Filsafat dan Politik. Universitas Islam Negeri Alauddin Makasar

Damsar. 2015. Pengantar Teori Sosiologi. Jakarta: Prenadamedia Group.

Poloma, M. 2004. Sosiologi Kontemporer. Jakarta: PT Raja Grafindo Persada.

Ritzer, George. (2014). Teori Sosiologi Modern Edisi Ketujuh. Jakarta: Prenadamedia Group.

Soekanto, Soerjono \& Budi S. 2013. Sosiologi Suatu Pengantar. Jakarta: Rajawali Pers.

Soekanto, Soerjono. 2006. Sosiologi Suatu Pengantar. Jakarta: Raja 
Grafindo Persada.

Sugiyono. 2014. Metode Penelitian

Kuantitatif Kualitatif, Dan R\&D.

Bandung: Alfabeta.

Susan, Novri. 2010. Pengantar Sosiologi

Konflik dan Isu- Isu Konflik

Kontemporer. Jakarta:Kencana

Prenada Media Group.

Weber, Max. Sosiologi. 2006. Yogyakarta: Pustaka Pelajar.

Wirawan. 2010. Konflik dan Manajemen Konflik. Jakarta: Salemba Empat.

Lingga, M.A. 2018. Jumlah Desa

Tertinggal Berkurang 6.518 Desa.

Diunduh pada 5 Februari 2019

pukul 18.45 WIB dari

https://ekonomi.kompas.com/read/

2018/12/10/133742026/bps-

jumlah-desa-tertinggal-berkurang6518-desa

Undang- Undang Nomor 6 Tahun 2014 Tentang Desa

Peraturan Daerah Sleman Nomor 16

Tahun 2016 tentang Tata Cara

Penangkatan dan Pemberhentian

Perangkat Desa 